\title{
RESULTS OF AMPUTATIONS
}

\author{
AT \\ UNIVERSITY-COLLEGE HOSPITAL，LONDON, \\ STATISTICALLY ARRANGED. \\ By JOHN PHILLIPS POTTER, EsQ., \\ LATE HOUSE-SURGEON.
}

WITH SOME REMARKS ON THE MODE OF AMPUTATION AND METHOD OF DRESSING THERE ADOPTED, BY ROBERT LISTON, ESQ.

Communicated by Mr. LISTON.

READ MAY 11TH, 1841.

Considerable attention has lately been drawn to the results of amputation generally, and to the comparative results of primary and secondary amputations in particular; and several able papers have appeared in the periodicals, containing more or less extensive statistical returns of cases treated at civil and military hospitals.

As the only chance of arriving at any safe and satisfactory conclusions in medical statistics depends on the number and accuracy of reports and cases from which such conclusions are to be drawn, it is of importance that as many of these should be collected as possible, from authentic sources, and particularly where the reports were taken during the progress of such cases. 
Much interesting information might thus be obtained from the records of our metropolitan and larger provincial hospitals; and if these were made public from time to time, the profession would be put in possession of a mass of facts which would afford valuable data, from which many practical inferences and useful rules might hereafter be derived.

With this persuasion I have examined the ReportBooks of University-College Hospital, and collected all the cases in which amputation has been performed, since the opening of the Institution, on the shoulder, arm, fore-arm, wrist, thigh, and leg.

These I have arranged in the form of tables, which, at the suggestion of my kind friend Mr. Liston, I venture to lay before this Society; and that gentleman has added some remarks on the mode of amputation which has been adopted, and the method of dressing which has been observed.

Though the period of time over which these observations extend is very limited (the first of the amputations having been performed no longer since than June 1835); and though the number of cases is consequently small, yet, as the series is complete as far as it goes, and as the cases have been treated on the same principles, and have been placed as nearly as possible under similar circumstances, it is hoped that this small contribution to surgical statistics may prove not entirely without interest.

The number of cases of amputation in the University-College Hospital, from the last day of June 1835 , to the termination of the year 1840 , a period 
of six years and a half, has been 66 , and of these, 56 have proved successful, whilst 10 have been attended with fatal results, at a variable period of time after the performance of the operation.

Of the 66 cases, 11 were subjected to amputation on account of severe compound fractures, and other injuries, the operations having been performed within 24 hours after the occurrence of the accident.

Out of these 11 cases of primary amputation, 3 terminated fatally, one in 7 days, one in 11 days, and one after the lapse of 48 days. The first of these fatal cases was of an unusually severe character, the patient having received, on the Birmingham Railway, compound fracture of both legs, fracture of the humerus, fracture of the ribs, and several severe contusions. In this instance both legs were removed, one in a few hours after the receipt of the injury, and the other a few days afterwards, in consequence of traumatic gangrene.

Seven out of the 11 cases recovered, and the stumps were healed completely, after the following times :-in 23 days, 30 days, 35 days, 48 days, 61 days, 75 days, and 1 after 146 days.

Table I. gives the parts which were amputated, and the results in each; from which it would appear that amputations on the lower extremity are, as might be expected, more dangerous to life than those of the upper extremity. 
TABLE I.

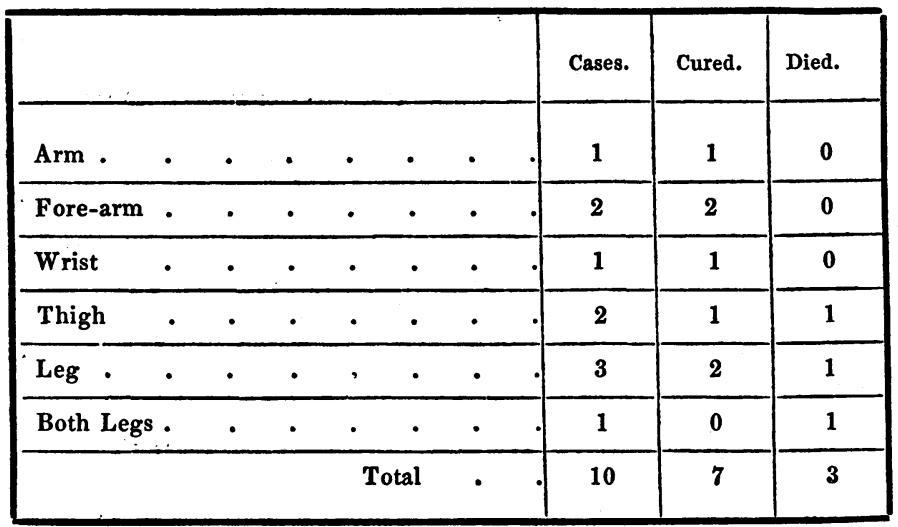

Proportion of Deaths barely 1 in 3 cases.

In the remaining 56 cases, amputation was performed on account of long-standing disease, or for injuries in which an attempt was made to save the limbs. Of this number, only seven died, giving a proportion of one death out of 8 cases.

Tables II. and III. give the parts at which amputation was performed, the nature of the different cases, and their results, together with the proportion of deaths under these different circumstances.

TABLE II.-56 Cases of Secondary Amputation.

\begin{tabular}{|c|c|c|c|c|c|c|c|c|}
\hline & & & & & $\begin{array}{l}\text { Number } \\
\text { of Cases. }\end{array}$ & Cured. & Died. & $\begin{array}{l}\text { Prop. of } \\
\text { Deaths. }\end{array}$ \\
\hline Shoulder & - & • & • & • & 1 & 1 & 0 & \\
\hline Arm & - & . & . & - & 7 & 5 & 2 & 1 in $3 \frac{1}{2}$ \\
\hline Fore-arm & • & . & . & • & 6 & 6 & 0 & \\
\hline Thigh & $\dot{\theta}^{\prime}$ & - & - & - & 20 & 17 & 3 & 1 in $6 \frac{2}{3}$ \\
\hline Leg & - & - & . & • & 22 & 20 & 2 & 1 in 11 \\
\hline \multicolumn{5}{|c|}{ Total } & 56 & 49 & 7 & \\
\hline
\end{tabular}


TABLE III.-Nature of the 56 Cases of Secondary Amputation.

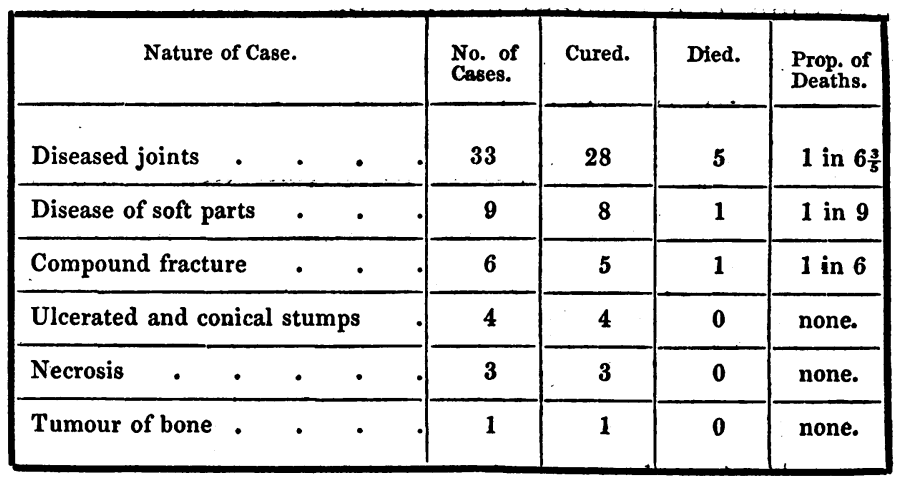

TABLE IV.-Ages of 66 Cases of Amputation.

\begin{tabular}{|c|c|c|c|c|c|c|}
\hline & & & $\begin{array}{l}\text { No. of } \\
\text { Cases. }\end{array}$ & Cured. & Died. & $\begin{array}{l}\text { Prop. of of } \\
\text { Deaths. }\end{array}$ \\
\hline From 3 to $1 \theta$ years & . & . & 6 & 6 & 0 & none. \\
\hline From 11 to 20 years & . $\quad$. & - & 16 & 13 & 3 & 1 in $4 \frac{1}{3}$ \\
\hline From 21 to 30 years & . $\quad$. & - & 17 & 15 & 2 & 1 in $7 \frac{1}{2}$ \\
\hline From 31 to 40 years & .. & - & 10 & 7 & 3 & 1 in $2 \frac{1}{3}$ \\
\hline From 41 to 50 years & . . & •. & 9 & 7 & 2 & 1 in $3 \frac{1}{2}$ \\
\hline From 51 to 60 years & . $\quad$. & - & 3 & 3 & 0 & none. \\
\hline From 61 to 70 years & .. & - & 4 & 4 & $\mathbf{0}$ & none. \\
\hline From 75 years & . $\quad$. & - & 1 & 1 & $\mathbf{0}$ & none. \\
\hline
\end{tabular}

Mode of Amputation.-In all the cases above mentioned, the flap amputation has been preferred as an operation which, it is believed, is not only more quickly performed, and with much less suffering to the patient, but is attended altogether with better results both as regards the form of the stump and the 
rapidity of its cure. The instrument used for the operation is a straight-backed knife, with an edge gently curving towards the point, and of a length varying with the size of the limb to be removed.

With only one exception, (in which the ordinary tourniquet was applied,) the artery of the limb was commanded by the fingers of an assistant, compression being made with moderate firmness over the axillary or brachial arteries in amputations on the upper extremity; and over the upper part of the femoral artery in operations on the lower limb.

It is found that very little blood is lost when this plan is adopted, because well-directed pressure immediately over the course of the principal artery of the limb completely arrests the flow of blood through that vessel and its offsets, whilst it does not in the least interfere with the return of blood by the veins, which, from their thinner parietes, are the first vessels to be compressed when the tourniquet is applied.

After the removal of the limb also, when the principal arteries have been tied, the smaller vessels are quickly and easily secured by slightly varying the pressure of the finger.

Another advantage derived from this mode of arresting the flow of blood through the limb, is that the operation itself is more conveniently performed than when the tourniquet is used. When both flaps have been cut, they are forcibly retracted by an assistant, whilst by a few sweeps of the knife the bone is denuded for some distance, and sawn through 
considerably above the point at which the first puncture in the skin was made. Now where a tourniquet is employed, the retraction of the flaps must be interfered with, to a great extent; but where pressure is made by the fingers only, and the rest of the limb is left free, this part of the operation is performed with perfect ease, and the motion of the saw, when applied close against the divided muscle, is not interfered with.

With regard to the method of performing the particular amputations, little need be said. In the case of the upper-arm, an external and an internal flap are made by transfixing on either side of the bone, and cutting from within outwards. The deep muscles are then separated from the bone, which is sawn through about an inch above the point at which the knife was entered at the commencement. In the case of the fore-arm however, it is found most convenient to make the first flap by cutting from the skin towards the bone, on the posterior aspect of the limb, and then transfixing beneath the mass of flexor muscles, and cutting an anterior flap from within outwards.

In amputation of the thigh, with one exception, in which Mr. Cooper pursued the plan of making lateral flaps immediately above the knee-joint, the flaps have generally been formed in such a manner that the line of union is directly across the limb.

The two flaps are made as nearly as possible of the same breadth and thickness; but the posterior one is made longer than the anterior one, in order 
that (in the ordinary semiflexed position of the stump) the bone may be easily covered, without any undue stretching of the parts.

The femur is, in most cases, sawn through about the middle of the shaft, or only slightly below that point ; both on account of the more complete manner in which the stump is received by the socket of the wooden leg, and because at the middle of the thigh a better cushion is formed by the soft parts around the bone.

Amputations of the thigh have been by no means uncommon; and (considering the size of the limb removed, compared with that of the whole body) very successful. Out of 22 cases, ( 2 primary, and 20 secondary,) only 4 deaths occurred.

Nearly all the amputations of the leg were performed close to the tuberosity of the tibia, the stump being left only of sufficient length to rest firmly on the cushion of the wooden leg.

The stump is then completely covered by the dress ; and, as it does not project much, it is not so liable to injury, or to become the seat of obstinate and painful ulceration, as is the case with stumps made at the middle of the leg or even a little higher.

Here again the ordinary flap amputation has been had recourse to ; a short anterior flap of skin being first made by dividing the skin over the upper end of the tibia in a semicircular form, and then the knife being made to transfix the leg, (at a variable distance behind the tibia and fibula, according to 
the size and degree of muscularity of the limb,) in order to form a suitable posterior flap.

The portion of muscle thus taken into the posterior flap gives a firmness and roundness to the stump when healed; and does not, in most cases, increase the amount of suppuration, or retard the union of the parts. The only cases in which this mode of amputation is inconvenient, are those in which the patient is muscular and in robust health; as in primary amputations for severe injuries, for example. Under these circumstances the muscles do not appear to have the same power of retraction as in patients who have long been in a low state of health. They are therefore much in the way when the stump is dressed; and by projecting beyond the skin, they prevent its union by the first intention, and occasionally cause some sloughing of the parts.

In two cases where, from the muscularity of the patient, this inconvenience was anticipated, Mr. Liston varied the operation in the following manner.

The anterior flap was made longer than usual, by curving the incision downwards in a semilunar form, and reflecting the skin from the front of the tibia. A posterior flap was then made, also of skin only, and of about the same length as the anterior one. This was reflected from the surface of the gastroenemius, and the deep structures divided down to the bones, which were separated from the muscles for a short distance before being sawn through.

In these cases the skin flaps healed with unusual rapidity; and the stumps were neat and well coм 2 
vered. In one case, union took place almost entirely by the first intention, and the patient was discharged cured in 25 days after the performance of the operation.

From the accompanying list it would appear that amputation of the leg is an operation which is not so frequently dangerous to life as might be expected. Out of 25 cases, 22 secondary' and 3 primary, 22 were successful, giving a proportion of about 1 fatal case out of every 8 .

This however does not accord with the returns of all hospitals.

Dr. Lowrie, in a paper published lately in the Medical Gazette, giving the results of amputations at the Glasgow Royal Infirmary since the commencement of that institution, recommends that the flap amputation immediately below the knee should be abandoned, as a very dangerous and frequently fatal proceeding.

He remarks that " of the more common amputations, that below the knee is the least favourable;" and he adds, that the returns from the Glasgow Infirmary, " by pointing out the danger of the common method of operating, should induce us never to remove more of the limb than will insure that the parts which form the stump are sound; and in all cases except those of necessity, to abandon the operation below the knee."

These observations have reference principally to amputations for disease; and it appears that out of 35 cases operated on in the Glasgow Infirmary, 12 
died; being a proportion of about 1 death in 3 cases.

This great mortality, however, cannot altogether depend on the particular kind of operation had recourse to, because out of 22 cases of secondary amputation of the leg, in University College Hospital, 20 were cured, giving a proportion of 1 death in 11 cases; by no means an unfavourable proportion.

Neither have these generally been found tedious cases; union by the first intention occurring frequently along half and sometimes nearly threefourths of the line of meeting of the flaps, and the remaining portions granulating without any great amount of suppuration. The average period of time which these patients remained in the hospital before their stumps were completely healed was from forty to fifty days.

Since, then, the high amputation is not necessarily more dangerous and fatal in its consequences than the operation below the middle of the leg, it does appear, at least in hospitals, to be on the whole the one to be preferred; for though a long stump may be more convenient for the instrument-maker to adapt artificial limbs to, yet to patients who are obliged to wear the common wooden pin, and labour for their living, it is found a very useless and frequently a much worse than useless appendage. As it projects far behind the other limb, it is constantly liable to injury; and after a time becomes ulcerated and irritable. The bone itself sometimes inflames, and the part becomes extremely painful and tender. 
This prevents the patient from pursuing his usual employments; and hence several have applied at the hospital who have been anxious to undergo a second amputation rather than suffer the pain and inconvenience of their former state any longer.

Mode of dressing the stump.-When ligatures have been tied around the principal arteries of a stump, the hæmorrhage from the smaller vessels (which are also tied in cases where the dressing is proceeded with immediately) is arrested by covering the recently-divided surfaces with lint, soaked in cold water.

This is removed and re-applied every few minutes at first, and then at longer intervals, until all bleeding has ceased; and in order to insure the actual application of the cold water to the bleeding surface, the coagula are from time to time gently removed. When the patient begins to recover the shock of the operation, one or two of these smaller arteries perhaps spout out afresh. These, however, if necessary, are easily secured, as the flaps are still separate and exposed: the greater number of vessels, on the contrary, become plugged up with fibrine, and retract within their sheaths.

Thus all chance of disturbance of the dressing, by effusion of blood between the flaps, is prevented; and that without having so many sources of irritation present in the stump, as when many vessels are secured by ligature.

Much has been said about the pain which this application of cold produces; but if done with the 
care and gentleness which should always be used in such cases, it is seldom much complained of. Where the patient is unusually nervous and susceptible of pain, tepid water, changed more frequently, may be used in a similar manner.

When all oozing of blood has ceased, and when the divided surfaces become glazed over, (which happens generally in from four to seven hours after the operation,) the wet lint and small remaining coagula are removed, and the dressing of the stump proceeded with. The flaps, which are in the most favourable state for union, are now brought accurately together, and retained by several points of interrupted suture. The number of sutures requisite for this purpose varies from two to four; but more than three are seldom used, even in amputation of the thigh. They are removed frequently in twelve or twenty-four hours; but if the flaps are large and heavy, and the threads cause no redness in the neighbouring skin, they may be left for several hours longer, to prevent any dragging on the recent adhesions. When the flaps are thus in apposition, the edges are more closely brought together by means of strips of plaster applied over the face of the stump, at a little distance from each other, so as to allow of the ready escape of discharge, and the abstraction of the sutures when necessary.

Instead of using, for this purpose, the ordinary resinous plaster, which is a dirty application, readily loosened by discharge, and frequently causing irritation and erythema of the skin, a far more convenient 
material is found in oiled silk or gold-beater's skin, spread with a solution of isinglass, which is allowed to dry. This plaster is sufficiently firm and tough to support the heaviest flaps; it is very adhesive, and being impervious to water, remains for many days without becoming detached; it does not irritate the skin; and, lastly, as it is quite transparent, the line of union may be seen distinctly through it, and additional support may, at any time, be given to a particular part, where it is seen that the lips of the wound are separating. This dressing is found perfectly sufficient for the first three or four days, or even longer in some cases; the stump being kept gently elevated on cushions covered with oiled silk. No bandage is applied at first, but the stump is left uncovered and cool.

In general, very little inflammatory swelling takes place under these circumstances, and what little does occur is not accompanied with pain, because there is nothing to constrict the parts, and prevent their enlargement.

A bandage is seldom applied before the third or fourth day, though occasionally it is made use of earlier, where the stump is large and heavy, and the union by the first intention not as extensive as usual.

At first, however, the roller is not brought over the face of the stump, but is only allowed to approach the end by circular turns. By this means the discharge is not confined, and the strips of plaster are left undisturbed, these being quite suffi- 
cient to prevent the lips of the wound from separating.

When suppuration is fairly established in those parts of the stump which have not united by the first intention, the plaster is usually removed, either entirely or in part, and the end of the stump dressed with lint dipped in tepid water, or in a gently-stimulating lotion, and covered with oiled silk. The bandage also is then brought over the end of the stump in such a manner as to support the flaps together, as the plaster hitherto has done. This simple kind of dressing has the advantage of being cool and clean: and as it may be easily removed, without much pain to the patient, it may be renewed daily.

Secondary hamorrhage.-One of the favourite objections to the method of amputating by flaps, is, that the vessels are divided obliquely, and that secondary hæmorrhage is consequently a more common occurrence, because the ligature, when tightened, does not bring together opposite parts of the artery. Whether this is a practical or merely a theoretical objection, can only be determined after comparing a considerable number of statistical returns of the results of the two different modes of operation.

In the sixty-six cases here collected, two instances occurred; both in amputation of the thigh. In one case the hæmorrhage proved fatal, as the patient was reduced to an extremely low state, by purulent discharge from the knee-joint, before he consented 
to amputation. The other patient recovered, after having, first the femoral and then the external iliac artery ligatured.

As this case was one of considerable interest, as illustrating a kind of hæmorrhagic tendency, which is probably dependent on a diseased state of the vessels, though such cannot be demonstrated, I may conclude these few remarks by a slight sketch of its principal features.

The patient, a swarthy middle-aged man, was admitted January 28th, 1839, with an immense ulcer over the front of the leg, which had existed for several years, and occasionally bled to a very considerable extent. There was also solid œdema of the lower part of the leg and foot, the skin and cellular tissue being greatly hypertrophied, and the epidermis developed into a kind of horny crust, similar to ichthyosis.

Though the foot was nearly twice its natural size, it was perfectly hard, and did not pit on pressure. The patient was prevented from working, and was beginning to lose his strength and appetite, when he applied, anxious to be relieved of his useless limb.

On the 4th of February he submitted to amputation of the thigh, the ulcer being too extensive to allow of the formation of sound flaps in the leg.

On the 12th of February, eight days after the amputation, secondary hæmorrhage occurred, which was, however, stopped by cold and pressure.

On the following day (13th) bleeding recommenced, but with much greater violence. Accord- 
ingly a ligature was placed round the femoral artery, just below Poupart's ligament.

On the 15th of February hæmorrhage to the amount of several ounces took place from a small artery (superficial external pudic), wounded in the operation of tying the femoral.

On the 27th of February the ligature came away from the femoral artery, without any bleeding, having been on only fourteen days.

On the 15th of March rapid bleeding occurred from the wound in the groin, which had nearly closed. This was for a time arrested by compression; but in the evening it again returned, and as the patient was excessively weak from a sloughing back, the external iliac artery was tied, as a last resource.

The following day several ounces of blood were again lost from the wound in the groin, but this was the last time of its occurrence.

On the 1st of April the ligature separated from the iliac artery, and the wound healed slowly but gradually. The patient after this by degrees recovered his strength and health, and was discharged the 5th of August 1839. He showed himself at the Hospital about a twelvemonth afterwards, in excellent health, apparently, and in full work. 
List of Amputations in University College Hospital, from June 1835 to January 1841.

MALE CASES.

\begin{tabular}{|c|c|c|c|c|c|c|c|c|}
\hline No. & $\begin{array}{l}\text { Name of } \\
\text { Patient. }\end{array}$ & Age. & $\begin{array}{l}\text { Nature of } \\
\text { the Case. }\end{array}$ & $\begin{array}{l}\text { Part ampu- } \\
\text { tated, and by } \\
\text { whom. }\end{array}$ & $\begin{array}{c}\text { Date of } \\
\text { Operation. }\end{array}$ & Result. & $\left|\begin{array}{c}\text { Date of } \\
\text { Discharge } \\
\text { or Death. }\end{array}\right|$ & $\begin{array}{c}\text { No. } \\
\text { of } \\
\text { Days. }\end{array}$ \\
\hline 1 & O'Daly, Martin. & 50 & $\begin{array}{l}\text { Painful and } \\
\text { conical stump. }\end{array}$ & $\begin{array}{l}\text { Fore arm, } \\
\text { Mr. Liston. }\end{array}$ & $\begin{array}{c}\text { June 30 } \\
1835 .\end{array}$ & Cured. & $\begin{array}{l}\text { Aug 5, } \\
1835 .\end{array}$ & 36 \\
\hline 2 & Philips, John. & 32 & $\begin{array}{c}\text { Compound frac- } \\
\text { ture of leg, } \\
\text { October } 24\end{array}$ & $\begin{array}{l}\text { Leg, } \\
\text { secondary, } \\
\text { Mr. Liston. }\end{array}$ & $\begin{array}{c}\text { Nov. } 16, \\
1835 .\end{array}$ & Cured. & $\begin{array}{c}\text { Dec. 19, } \\
1835 .\end{array}$ & 33 \\
\hline 3 & Church, Jasper. & 50 & $\begin{array}{c}\text { Disease of bones } \\
\text { of foot. }\end{array}$ & $\begin{array}{c}\text { Leg, } \\
\text { Mr. Liston. }\end{array}$ & $\begin{array}{c}\text { July } 1, \\
1836 .\end{array}$ & Cured. & \begin{tabular}{|} 
Sept. 1, \\
1836.
\end{tabular} & 62 \\
\hline 4 & Fenning, James. & 13 & Painful stump. & $\begin{array}{l}\text { Thigh, } \\
\text { Mr. Liston. }\end{array}$ & $\begin{array}{c}\text { Dec. 2, } \\
1836 .\end{array}$ & Cured. & $\begin{array}{l}\text { Jan. 2, } \\
1837 .\end{array}$ & 32 \\
\hline 5 & Smith, Henry. & 23 & Disease of ankle. & $\begin{array}{c}\text { Leg, } \\
\text { Mr. Liston. }\end{array}$ & $\begin{array}{l}\text { Dec. 5, } \\
1836 .\end{array}$ & Cured. & $\begin{array}{c}\text { Not } \\
\text { entered. }\end{array}$ & - \\
\hline 6 & Miles, Daniel. & 4 & Disease of ankle. & $\begin{array}{l}\text { Leg, } \\
\text { Mr. Liston. }\end{array}$ & $\begin{array}{c}\text { March 22, } \\
1837 .\end{array}$ & Cured. & $\begin{array}{c}\text { April 12, } \\
1837 .\end{array}$ & 21 \\
\hline 7 & Dixon, John. & 61 & Diseased wrist. & $\begin{array}{c}\text { Fore arm, } \\
\text { Mr. Liston. }\end{array}$ & $\begin{array}{c}\text { April 20, } \\
1837 .\end{array}$ & Cured. & $\begin{array}{c}\text { Not } \\
\text { Entered. }\end{array}$ & - \\
\hline 8 & Brewer, Francis. & 18 & Diseased elbow. & $\begin{array}{l}\text { Fore arm, } \\
\text { Mr. Quain. }\end{array}$ & $\begin{array}{c}\text { May 4, } \\
1837 .\end{array}$ & Cured. & $\begin{array}{c}\text { June 24, } \\
1837 .\end{array}$ & 51 \\
\hline 9 & $\begin{array}{l}\text { Whetstone, } \\
\text { Thomas }\end{array}$ & 45 & Ulcer of leg. & $\begin{array}{l}\text { Leg, } \\
\text { Mr. Liston. }\end{array}$ & $\begin{array}{c}\text { April 5, } \\
\text { 1837. }\end{array}$ & Died. & $\begin{array}{c}\text { May 14, } \\
1837 .\end{array}$ & 39 \\
\hline 10 & Dyer, Henry. & 13 & $\begin{array}{c}\text { Diseased ankle, } \\
\text { necrosis of tibia. }\end{array}$ & $\begin{array}{l}\text { Leg, } \\
\text { Mr. Liston. }\end{array}$ & $\begin{array}{c}\text { April 5, } \\
1837 .\end{array}$ & Cured. & $\begin{array}{c}\text { Not } \\
\text { Entered. }\end{array}$ & - \\
\hline 11 & Hennell, William. & 29 & $\begin{array}{l}\text { Compound frac- } \\
\text { ture of the leg. }\end{array}$ & $\begin{array}{l}\text { Thigh, } \\
\text { primary, } \\
\text { Mr. Liston. }\end{array}$ & $\begin{array}{c}\text { June 23, } \\
1837 .\end{array}$ & Cured. & $\begin{array}{c}\text { Aug. 10, } \\
1837 .\end{array}$ & 48 \\
\hline 12 & Backer, George. & 21 & $\begin{array}{l}\text { Compound frac- } \\
\text { ture, \&c. of arm. }\end{array}$ & $\begin{array}{c}\text { Fore arm, } \\
\text { primary, } \\
\text { Mr. Cooper. }\end{array}$ & $\begin{array}{c}\text { Aug. 1, } \\
1837 .\end{array}$ & Cured. & $\begin{array}{c}\text { Aug. 31, } \\
1837 .\end{array}$ & 30 \\
\hline 13 & Millet, William. & 14 & Necrosis of tibia. & $\begin{array}{c}\text { Leg, } \\
\text { Mr. Liston. }\end{array}$ & $\begin{array}{c}\text { Aug. 18, } \\
1837 .\end{array}$ & Cured. & $\begin{array}{l}\text { Oct. 4, } \\
1837 .\end{array}$ & 46 \\
\hline 14 & Eyres, George. & 37 & $\begin{array}{c}\text { Compound frac- } \\
\text { ture and contused } \\
\text { hand. }\end{array}$ & $\begin{array}{c}\text { Wrist joint, } \\
\text { primary, } \\
\text { Mr. Liston. }\end{array}$ & $\begin{array}{c}\text { Aug. 24, } \\
1837 .\end{array}$ & Cured. & $\begin{array}{c}\text { Sept. 29, } \\
1837 .\end{array}$ & 35 \\
\hline
\end{tabular}


RESULTS OF AMPUTATIONS.

\begin{tabular}{|c|c|c|c|c|c|c|c|c|}
\hline No. & $\begin{array}{l}\text { Name of } \\
\text { Patient. }\end{array}$ & Age. & $\begin{array}{l}\text { Nature of } \\
\text { the Case. }\end{array}$ & $\begin{array}{l}\text { Part ampu- } \\
\text { tated, and by } \\
\text { whom. }\end{array}$ & $\begin{array}{c}\text { Date of } \\
\text { Operation. }\end{array}$ & Result. & $\begin{array}{l}\text { Date of } \\
\text { Discharge } \\
\text { or Death. }\end{array}$ & $\begin{array}{c}\text { No. } \\
\text { of } \\
\text { Days. }\end{array}$ \\
\hline 15 & Hesson, James. & 19 & $\begin{array}{l}\text { Compound frac- } \\
\text { ture, with severe } \\
\text { laceration of leg } \\
\text { and foot. }\end{array}$ & $\begin{array}{l}\text { Thigh, } \\
\text { primary, } \\
\text { Mr. Liston. }\end{array}$ & $\begin{array}{c}\text { Sept. 18, } \\
1837 .\end{array}$ & Died. & $\begin{array}{c}\text { Nov. 5, } \\
1837 \text {. }\end{array}$ & 48 \\
\hline 16 & $\begin{array}{l}\text { Robinson, } \\
\text { George. }\end{array}$ & 31 & $\begin{array}{l}\text { Compound frac- } \\
\text { ture of both legs, } \\
\text { of humerus and } \\
\text { other injuries. }\end{array}$ & $\begin{array}{l}\text { One leg, } \\
\text { primary, } \\
\text { Mr. Liston. } \\
\text { Other leg, } \\
\text { secondary, } \\
\text { Mr. Quain. }\end{array}$ & $\begin{array}{l}\text { Nov. 4, } \\
1837 .\end{array}$ & Died. & $\begin{array}{c}\text { Nov. 11, } \\
1837 .\end{array}$ & 7 \\
\hline 17 & Compton, Henry. & 25 & $\begin{array}{c}\text { Compound frac- } \\
\text { ture of leg. }\end{array}$ & $\begin{array}{c}\text { Leg, primary, } \\
\text { Mr. Liston. }\end{array}$ & \begin{tabular}{|} 
Dec. 30, \\
1837.
\end{tabular} & Cured. & $\begin{array}{c}\text { May 22, } \\
1838 .\end{array}$ & 146 \\
\hline 18 & Lee, Charles. & 39 & Diseased knee. & $\begin{array}{l}\text { Thigh, } \\
\text { Mr. Liston. }\end{array}$ & $\begin{array}{l}\text { Jan. 8, } \\
1838 .\end{array}$ & Cured. & $\begin{array}{c}\text { March 30, } \\
1838 .\end{array}$ & 83 \\
\hline 19 & Davis, Thomas. & 51 & Diseased knee. & $\begin{array}{l}\text { Thigh, } \\
\text { Mr. Cooper. }\end{array}$ & $\begin{array}{c}\text { Jan. 11, } \\
1838 .\end{array}$ & Cured. & $\begin{array}{c}\text { March 12, } \\
1838 .\end{array}$ & 62 \\
\hline 20 & Hellaby. & 23 & $\begin{array}{l}\text { Scrophulous dis- } \\
\text { ease of ankle. }\end{array}$ & $\begin{array}{l}\text { Leg, } \\
\text { Mr. Liston. }\end{array}$ & $\begin{array}{r}\text { March } \\
1838 .\end{array}$ & Cured. & - & - \\
\hline 21 & Seabright. & 43 & Diseased ankle. & $\begin{array}{c}\text { Leg, } \\
\text { Mr. Liston. }\end{array}$ & $\begin{array}{c}\text { April 20, } \\
1838 .\end{array}$ & Cured. & $\begin{array}{c}\text { June 2, } \\
1838 .\end{array}$ & 43 \\
\hline 22 & Earp. & 63 & $\begin{array}{l}\text { Diseased wrist } \\
\text { and bones of } \\
\text { hand. }\end{array}$ & $\begin{array}{l}\text { Fore-arm, } \\
\text { Mr. Liston. }\end{array}$ & $\begin{array}{c}\text { Oct. } 15, \\
1838 .\end{array}$ & Cured. & $\begin{array}{l}\text { Dec. } 1 \text {, } \\
1838 .\end{array}$ & 47 \\
\hline 23 & Tuck. & 26 & $\begin{array}{c}\text { Diseased ankle- } \\
\text { joint, \&c. }\end{array}$ & $\begin{array}{l}\text { Leg, } \\
\text { Mr. Liston. }\end{array}$ & $\begin{array}{c}\text { Oct. 15, } \\
1838 .\end{array}$ & Cured. & $\begin{array}{c}\text { Nov. 30, } \\
1838 .\end{array}$ & 46 \\
\hline 24 & Cater. & 30 & $\begin{array}{c}\text { Disease of knee } \\
\text { from lacerated } \\
\text { wound, Nov. } 18\end{array}$ & $\begin{array}{l}\text { Thigh, } \\
\text { secondary, } \\
\text { Mr. Liston. }\end{array}$ & $\begin{array}{c}\text { Dec. } 7, \\
1838 .\end{array}$ & Died. & $\begin{array}{c}\text { Dec. 31, } \\
1838 .\end{array}$ & 24 \\
\hline 25 & Smart. & 45 & $\begin{array}{c}\text { Contusion and } \\
\text { laceration, \&c., } \\
\text { of hand and wrist, } \\
\text { fracture, \&c. }\end{array}$ & $\begin{array}{l}\text { Fore arm, } \\
\text { primary, } \\
\text { Mr. Quain. }\end{array}$ & $\begin{array}{l}\operatorname{Jan} 4, \\
1839 .\end{array}$ & Cured. & $\begin{array}{c}\text { Feb. 30, } \\
1839 .\end{array}$ & 61 \\
\hline 26 & Woodroffe. & 45 & $\begin{array}{l}\text { Old ulcer, and } \\
\text { solid œdema of } \\
\text { leg and foot. }\end{array}$ & $\begin{array}{l}\text { Thigh, } \\
\text { Mr. Liston. }\end{array}$ & $\begin{array}{c}\text { Feb. 4, } \\
1839\end{array}$ & Cured. & $\begin{array}{l}\text { Aug. 5, } \\
1839 .\end{array}$ & 182 \\
\hline 27 & Dance. & 3 & Diseased elbow. & $\begin{array}{l}\text { Upper arm, } \\
\text { Mr. Liston. }\end{array}$ & $\begin{array}{c}\text { Mar. 15, } \\
1839 .\end{array}$ & Cured. & $\begin{array}{c}\text { April 17, } \\
1839 .\end{array}$ & 33 \\
\hline 28 & Reed. & 11 & $\begin{array}{c}\text { Diseased ankle- } \\
\text { joint. }\end{array}$ & $\begin{array}{l}\text { Leg, } \\
\text { Mr. Liston. }\end{array}$ & $\begin{array}{c}\text { Mar. 21, } \\
1839 .\end{array}$ & Cured. & $\begin{array}{c}\text { April 29, } \\
1839 .\end{array}$ & 39 \\
\hline 29 & Fox. & 27 & $\begin{array}{c}\text { Disease of carpal } \\
\text { bones. }\end{array}$ & $\begin{array}{l}\text { Fore-arm, } \\
\text { Mr. Liston. }\end{array}$ & $\begin{array}{c}\text { May 29, } \\
1839 .\end{array}$ & Cured. & $\begin{array}{c}\text { July } 12 \\
1839 .\end{array}$ & 44 \\
\hline
\end{tabular}




\begin{tabular}{|c|c|c|c|c|c|c|c|c|}
\hline No. & $\begin{array}{l}\text { Name of } \\
\text { Patient. }\end{array}$ & Age. & $\begin{array}{l}\text { Nature of } \\
\text { the Case. }\end{array}$ & $\begin{array}{l}\text { Part amputated, } \\
\text { and by whom. }\end{array}$ & $\begin{array}{c}\text { Date of } \\
\text { Operation. }\end{array}$ & Result. & $\begin{array}{c}\text { Date of } \\
\text { Discharge } \\
\text { or Death. }\end{array}$ & $\begin{array}{c}\text { No. } \\
\text { of } \\
\text { Days. }\end{array}$ \\
\hline 30 & Steele. ' & 18 & $\begin{array}{c}\text { Severe fracture } \\
\text { and laceration of } \\
\text { leg and foot. }\end{array}$ & $\begin{array}{l}\text { Leg, primary, } \\
\text { Mr. Liston. }\end{array}$ & $\begin{array}{l}\text { Sept. 6, } \\
1839 .\end{array}$ & Cured. & $\begin{array}{l}\text { Nov. 20, } \\
1839 .\end{array}$ & 75 \\
\hline 31 & Lyon. & 28 & $\begin{array}{l}\text { Compound frac- } \\
\text { ture of femur, } \\
\text { September } 2 \text {. }\end{array}$ & \begin{tabular}{|c|} 
Thigh, \\
secondary, \\
Mr. Cooper.
\end{tabular} & $\begin{array}{l}\text { Oct. 5, } \\
1839 .\end{array}$ & Died. & $\begin{array}{c}\text { Oct. 24, } \\
1839 .\end{array}$ & 19 \\
\hline 32 & Bentley. & 11 & $\begin{array}{l}\text { Scrophulous dis- } \\
\text { ease of foot. }\end{array}$ & $\begin{array}{l}\text { Leg, } \\
\text { Mr. Liston. }\end{array}$ & $\begin{array}{c}\text { Sept. } 13 . \\
1839 .\end{array}$ & Cured. & \begin{tabular}{|} 
Oct. 19, \\
1839.
\end{tabular} & 36 \\
\hline 33 & North. & 32 & $\begin{array}{l}\text { Painful and coni- } \\
\text { cal stump of thigh. }\end{array}$ & $\begin{array}{l}\text { Thigh, } \\
\text { Mr. Liston. }\end{array}$ & $\begin{array}{c}\text { Dec. 19, } \\
1839 .\end{array}$ & Cured. & \begin{tabular}{|c|} 
Jan. 27, \\
1840.
\end{tabular} & 39 \\
\hline 34 & Blackmore. & 40 & $\begin{array}{l}\text { Disease of } \\
\text { elbow and fore- } \\
\text { arm. }\end{array}$ & $\begin{array}{l}\text { Upper-arm, } \\
\text { Mr. Liston. }\end{array}$ & $\begin{array}{c}\text { Jan. 20, } \\
1840 .\end{array}$ & Died. & $\begin{array}{l}\text { March } \\
1840 .\end{array}$ & - \\
\hline 35 & Bruce. & 40 & $\begin{array}{l}\text { Disease of } \\
\text { elbow-joint. }\end{array}$ & $\begin{array}{l}\text { Upper-arm, } \\
\text { Mr. Liston. }\end{array}$ & $\begin{array}{c}\text { Jan. 31, } \\
1840 .\end{array}$ & Died. & $\begin{array}{c}\text { Feb. 2, } \\
1840 .\end{array}$ & 2 \\
\hline 36 & Nicholson. & 46 & $\begin{array}{c}\text { Compound frac- } \\
\text { ture of leg. }\end{array}$ & $\begin{array}{l}\text { Leg, primary, } \\
\text { Mr. Cooper. }\end{array}$ & $\begin{array}{c}\text { Feb. 17 } \\
1840 .\end{array}$ & Died. & $\begin{array}{c}\text { Feb. 28, } \\
1840 .\end{array}$ & 11 \\
\hline 37 & Clavidge. & 64 & $\begin{array}{l}\text { Extensive ulcer } \\
\text { of leg, \&c. }\end{array}$ & $\begin{array}{c}\text { Leg, } \\
\text { Mr. Quain. }\end{array}$ & $\begin{array}{c}\text { March 21, } \\
1840 .\end{array}$ & Cured. & $\begin{array}{c}\text { June 26, } \\
1840 .\end{array}$ & 97 \\
\hline 38 & Wright. & 60 & $\begin{array}{c}\text { Malignant ulcer } \\
\text { of leg. }\end{array}$ & $\begin{array}{l}\text { Thigh, } \\
\text { Mr. Liston. }\end{array}$ & \begin{tabular}{|} 
June 24, \\
1840.
\end{tabular} & Cured. & $\begin{array}{c}\text { Aug. 20, } \\
1840 .\end{array}$ & 57 \\
\hline 39 & Lay. & 18 & Diseased ancle. & $\begin{array}{l}\text { Leg, } \\
\text { Mr. Quain. }\end{array}$ & $\begin{array}{c}\text { June } 30 \\
1840 .\end{array}$ & Cured. & $\begin{array}{c}\text { July } 31, \\
1840 .\end{array}$ & 31 \\
\hline 40 & Redding. & 40 & Diseased knee. & $\begin{array}{l}\text { Thigh, } \\
\text { Mr. Quain. }\end{array}$ & $\begin{array}{c}\text { Aug. 5, } \\
1840 .\end{array}$ & Cured. & $\begin{array}{c}\text { Sept. 12, } \\
1840 .\end{array}$ & 38 \\
\hline 41 & Willis. & 42 & $\begin{array}{c}\text { Compound frac- } \\
\text { ture of leg, } \\
\text { June } 29 .\end{array}$ & $\begin{array}{c}\text { Leg, } \\
\text { secondary, } \\
\text { Mr. Liston. }\end{array}$ & $\begin{array}{c}\text { Sept. 2, } \\
1840 .\end{array}$ & Cured. & $\begin{array}{c}\text { Dec. } 12, \\
1840 .\end{array}$ & 103 \\
\hline 42 & Kent, James. & 14 & $\begin{array}{c}\text { Abscess of knee- } \\
\text { joint. }\end{array}$ & $\begin{array}{l}\text { Thigh, } \\
\text { Mr. Liston. }\end{array}$ & $\begin{array}{c}\text { Sept. } 9, \\
1840 .\end{array}$ & Cured. & $\begin{array}{c}\text { Oct. 31, } \\
1840 .\end{array}$ & 52 \\
\hline 43 & Meedes, Thomas. & 16 & $\begin{array}{l}\text { Inconvenient } \\
\text { and ulcerated } \\
\text { stump. }\end{array}$ & $\begin{array}{l}\text { Leg, } \\
\text { Mr. Liston. }\end{array}$ & $\begin{array}{c}\text { Sept. 9, } \\
1840 .\end{array}$ & Cured. & $\begin{array}{c}\text { Nov. } 3, \\
1840 .\end{array}$ & 55 \\
\hline 44 & Dale, John. & 27 & $\begin{array}{c}\text { Disease of ankle- } \\
\text { joint. }\end{array}$ & $\begin{array}{l}\text { Leg, } \\
\text { Mr. Liston. }\end{array}$ & $\begin{array}{c}\text { Sept. 9, } \\
1840 .\end{array}$ & Cured. & $\begin{array}{c}\text { Nov. } 10, \\
1840 .\end{array}$ & 62 \\
\hline 45 & Brown, Thomas. & 22 & $\begin{array}{c}\text { Encephaloid } \\
\text { tumour of hand. }\end{array}$ & $\begin{array}{l}\text { Fore-arm, } \\
\text { Mr. Liston. }\end{array}$ & $\begin{array}{c}\text { Oct. 30, } \\
1840 .\end{array}$ & Cured. & $\begin{array}{c}\text { Dec. 9, } \\
1840 .\end{array}$ & 40 \\
\hline 46 & Turton, John. & 63 & $\begin{array}{l}\text { Erysipelas of } \\
\text { arm, \&c. \&c. }\end{array}$ & $\begin{array}{l}\text { Upper-arm, } \\
\text { Mr. Quain. }\end{array}$ & $\begin{array}{c}\text { Oct. 30, } \\
1840 .\end{array}$ & Cured. & $\begin{array}{c}\text { Dec. 31, } \\
1840 .\end{array}$ & 62 \\
\hline
\end{tabular}


FEMALE CASES.

\begin{tabular}{|c|c|c|c|c|c|c|c|c|}
\hline No. & $\begin{array}{l}\text { Name of } \\
\text { Patient. }\end{array}$ & Age. & $\begin{array}{l}\text { Nature of } \\
\text { the Case. }\end{array}$ & $\begin{array}{c}\text { Part amputated, } \\
\text { and by whom. }\end{array}$ & $\begin{array}{c}\text { Date of } \\
\text { Operation. }\end{array}$ & Result. & $\begin{array}{l}\text { Date of } \\
\text { Discharge } \\
\text { or Deatk. }\end{array}$ & $\begin{array}{c}\text { No. } \\
\text { of } \\
\text { Days. }\end{array}$ \\
\hline 47 & Arnold, Sarah. & 75 & Gangrena senilis. & $\begin{array}{l}\text { Upper-arm, } \\
\text { Mr. Liston. }\end{array}$ & $\begin{array}{c}\text { Feb. 2, } \\
1835 .\end{array}$ & Cured. & $\begin{array}{c}\text { May } 12, \\
1835 .\end{array}$ & 100 \\
\hline 48 & $\begin{array}{c}\text { Brooks, Mary } \\
\text { Ann. }\end{array}$ & 50 & $\begin{array}{l}\text { Osteo sarcoma of } \\
\text { foot and ankle. }\end{array}$ & $\begin{array}{c}\text { Leg, } \\
\text { Mr. Liston. }\end{array}$ & $\begin{array}{c}\text { Aug. 25, } \\
1835 .\end{array}$ & Cured. & $\begin{array}{c}\text { Oct. 10, } \\
1835 .\end{array}$ & 46 \\
\hline 49 & Parish, Catharine & 6 & $\begin{array}{l}\text { Diseased knee- } \\
\text { joint. }\end{array}$ & $\begin{array}{l}\text { Thigh, } \\
\text { Mr. Liston. }\end{array}$ & $\begin{array}{c}\text { March 27, } \\
1837\end{array}$ & Cured. & $\begin{array}{c}\text { April 18, } \\
1837 .\end{array}$ & 22 \\
\hline $\mathbf{5 0}$ & Luck, Sarah. & 35 & $\begin{array}{l}\text { Compound frac- } \\
\text { ture of leg, } \\
\text { March 27. }\end{array}$ & $\begin{array}{l}\text { Thigh, } \\
\text { secondary, } \\
\text { Mr. Liston. }\end{array}$ & $\begin{array}{c}\text { May } 19, \\
1837\end{array}$ & Cured. & - & - \\
\hline 51 & $\begin{array}{l}\text { Hayman, } \\
\text { Eleanor. }\end{array}$ & 42 & $\begin{array}{c}\text { Disease of elbow } \\
\text { following burn } \\
\text { and injury. }\end{array}$ & $\begin{array}{l}\text { Upper-arm, } \\
\text { Mr. Liston. }\end{array}$ & $\begin{array}{c}\text { Dec. } 21, \\
1837 .\end{array}$ & Cured. & $\begin{array}{l}\text { Jan. 9, } \\
1838 .\end{array}$ & 19 \\
\hline 52 & Harrison, Phillis. & 21 & $\begin{array}{c}\text { Abscess and } \\
\text { hectic following } \\
\text { erysipelas. }\end{array}$ & $\begin{array}{l}\text { Thigh, } \\
\text { Mr. Liston. }\end{array}$ & $\begin{array}{c}\text { Jan. 12, } \\
1838 .\end{array}$ & Cured. & $\begin{array}{c}\text { March 19, } \\
1838 .\end{array}$ & 66 \\
\hline 53 & Wood, Sarah. & 16 & $\begin{array}{l}\text { Gangrene of arm } \\
\text { following com- } \\
\text { pound fracture. }\end{array}$ & $\begin{array}{c}\text { Shoulder-joint, } \\
\text { secondary, } \\
\text { Mr. Liston. }\end{array}$ & $\begin{array}{c}\text { March 14, } \\
1838\end{array}$ & Cured. & $\begin{array}{c}\text { June } 15, \\
1838\end{array}$ & 92 \\
\hline 54 & King, Ann. & 6 & $\begin{array}{c}\text { Disease of elbow- } \\
\text { joint. }\end{array}$ & $\begin{array}{l}\text { Upper-arm, } \\
\text { Mr. Liston. }\end{array}$ & $\begin{array}{c}\text { July } 9 \\
1838 .\end{array}$ & Cured. & $\begin{array}{c}\text { Aug. 1, } \\
1838 .\end{array}$ & 23 \\
\hline 55 & Miller,Elizabeth. & 9 & $\begin{array}{c}\text { Scrophulous } \\
\text { disease of knee. }\end{array}$ & $\begin{array}{l}\text { Thigh, } \\
\text { Mr. Liston. }\end{array}$ & $\begin{array}{l}\text { Oct. 3, } \\
1838 .\end{array}$ & Cured. & $\begin{array}{c}\text { Oct. 31, } \\
1838 .\end{array}$ & 27 \\
\hline 56 & Edmead, Sarah. & 16 & $\begin{array}{c}\text { Strumous disease } \\
\text { of tarsus and } \\
\text { metatarsus. }\end{array}$ & $\begin{array}{c}\text { Leg, } \\
\text { Mr. Cooper. }\end{array}$ & $\begin{array}{c}\text { Oct. 27, } \\
1838 .\end{array}$ & Died. & $\begin{array}{c}\text { Nov. 27, } \\
1838 .\end{array}$ & 31 \\
\hline 57 & Bevan, Margaret. & 26 & $\begin{array}{c}\text { Tumour of tibia } \\
\text { in ham. }\end{array}$ & $\begin{array}{c}\text { Thigh, } \\
\text { Mr. Liston. }\end{array}$ & $\begin{array}{c}\text { Feb. 8, } \\
1839 .\end{array}$ & Cured. & $\begin{array}{c}\text { April 24, } \\
1839 .\end{array}$ & 75 \\
\hline 58 & Nash, Eliza. & 5 & $\begin{array}{l}\text { Compound frac- } \\
\text { ture of fore-arm } \\
\text { and elbow-joint. }\end{array}$ & $\begin{array}{l}\text { Upper-arm, } \\
\text { primary, } \\
\text { Mr. Liston. }\end{array}$ & $\begin{array}{c}\text { June 27, } \\
1839 .\end{array}$ & Cured. & $\begin{array}{c}\text { July 20, } \\
1839 .\end{array}$ & 23 \\
\hline 59 & Kingston, Janf. & 22 & Disease of knee. & $\begin{array}{l}\text { Thigh, } \\
\text { Mr. Liston. }\end{array}$ & $\begin{array}{c}\text { Oct. 22, } \\
1839 .\end{array}$ & Cured. & $\begin{array}{c}\text { Dec. } 11, \\
1839 .\end{array}$ & 50 \\
\hline 60 & $\begin{array}{c}\text { Turner, Eliza- } \\
\text { beth. }\end{array}$ & 16 & Disease of knee. & $\begin{array}{l}\text { Thigh, } \\
\text { Mr. Liston. }\end{array}$ & $\begin{array}{c}\text { Jan. } 31 \\
1840 .\end{array}$ & Cured. & $\begin{array}{c}\text { April 2, } \\
1840 .\end{array}$ & 61 \\
\hline 61 & $\begin{array}{c}\text { Hatwell, Eliza- } \\
\text { beth. }\end{array}$ & 23 & Disease of knee. & $\begin{array}{l}\text { Thigh, } \\
\text { Mr. Liston. }\end{array}$ & $\begin{array}{c}\text { Jan. 31, } \\
1840 .\end{array}$ & Cured. & $\begin{array}{c}\text { April 4, } \\
1840 .\end{array}$ & 63 \\
\hline
\end{tabular}


MR. POTTER ON THE RESULTS OF AMPUTATIONS.

\begin{tabular}{|c|c|c|c|c|c|c|c|c|}
\hline No. & $\begin{array}{l}\text { Name of } \\
\text { Patient. }\end{array}$ & Age. & $\begin{array}{l}\text { Nature of } \\
\text { the Case. }\end{array}$ & $\begin{array}{l}\text { Part amputated, } \\
\text { and by whom. }\end{array}$ & $\begin{array}{c}\text { Date of } \\
\text { Operation. }\end{array}$ & Result. & \begin{tabular}{|l} 
Date of \\
Discharge \\
or Death.
\end{tabular} & $\begin{array}{c}\text { No. } \\
\text { of } \\
\text { Days. }\end{array}$ \\
\hline 62 & Thrift, Letitia. & 18 & Disease of knee. & $\begin{array}{l}\text { Thigh, } \\
\text { Mr. Liston. }\end{array}$ & $\begin{array}{c}\text { April 6, } \\
1840 .\end{array}$ & Died. & $\begin{array}{c}\text { April 23, } \\
1840 .\end{array}$ & 17 \\
\hline 63 & Knight, Caroline. & 21 & $\begin{array}{c}\text { Extensive } \\
\text { necrosis of tibia. }\end{array}$ & $\begin{array}{l}\text { Leg, } \\
\text { Mr. Quain. }\end{array}$ & $\begin{array}{c}\text { April 9, } \\
1840 .\end{array}$ & Cured. & $\begin{array}{c}\text { May 30, } \\
1840 .\end{array}$ & 51 \\
\hline 64 & $\begin{array}{l}\text { McDonald, } \\
\text { Mary. }\end{array}$ & 20 & $\begin{array}{l}\text { Disease of } \\
\text { knee-joint. }\end{array}$ & $\begin{array}{l}\text { Thigh, } \\
\text { Mr. Quain. }\end{array}$ & $\begin{array}{c}\text { Aug. 5, } \\
1840 .\end{array}$ & Cured. & $\begin{array}{c}\text { Aug. 31, } \\
1840 .\end{array}$ & 26 \\
\hline 65 & $\begin{array}{l}\text { Keating, Hen- } \\
\text { rietta. }\end{array}$ & 22 & $\begin{array}{c}\text { Disease of ankle- } \\
\text { joint. }\end{array}$ & $\begin{array}{l}\text { Leg, } \\
\text { Mr. Liston. }\end{array}$ & $\begin{array}{l}\text { Oct. 5, } \\
1840 .\end{array}$ & Cured. & $\begin{array}{c}\text { Oct. 30, } \\
1840 .\end{array}$ & 25 \\
\hline 66 & Halwell. & 40 & $\begin{array}{c}\text { Compound frac- } \\
\text { ture of leg, } \\
\text { abscess. }\end{array}$ & $\begin{array}{l}\text { Leg, } \\
\text { secondary, } \\
\text { Mr. Quain. }\end{array}$ & $\begin{array}{c}\text { Nov. } 12, \\
1840 .\end{array}$ & Cured. & $\begin{array}{l}\text { Jan. 1, } \\
1841 .\end{array}$ & 44 \\
\hline
\end{tabular}

